\title{
Cholesterol Level in Covid-19 Patients Related to Severity and Mortality: A Case Series and Literature Review
}

\author{
Anggarda Kristianti Utomo', Haryati² \\ ${ }^{1}$ Department of Internal Medicine, Faculty of Medicine Universitas Lambung Mangkurat/ \\ Ulin Regional Hospital, Banjarmasin \\ 2Department of Pulmonology and Respiratory Medicine, Faculty of Medicine \\ Universitas Lambung Mangkurat - Ulin Regional Hospital, Banjarmasin
}

\section{Corresponding Author:}

Haryati | Departement of Pulmonology and Respiratory Medicine, Faculty of Medicine Universitas Lambung Mangkurat - Ulin Regional Hospital, Banjarmasin | haryatiharsono@yahoo.com

Submitted: July $12^{\text {th }}, 2021$

Accepted: August $18^{\text {th }}, 2021$

Published: October $15^{\text {th }}, 2021$

Respir Sci. 2021; 2(1): 28-44

https://doi.org/10.36497/respirsci.v1i3.28

\begin{abstract}
Coronavirus Disease 2019 (COVID-19) is a communicable disease caused by Severe Acute Respiratory Syndrome Coronavirus 2 (SARS-CoV-2). December 2019 in Wuhan, China, is the time and place where the first pneumonia case which SARS-CoV-2 causes was found, and WHO designated COVID-19 as a pandemic by March 2020. There are reported cases of dyslipidemia associated with SARS patients, albeit rare. Several case reports showed lower cholesterol levels compared to healthy subjects. Therefore, some argued that dyslipidemia could occur in COVID-19. Several studies have revealed that hypolipidemia is positively correlated with the severity of COVID-19. In Ulin Regional Hospital Banjarmasin, several cases found higher cholesterol levels in asymptomatic and mild-moderate COVID-19 survivor compared to patients with severe/critical COVID-19and non-survivor. Two patients in the nonsurvivor group showed a significant decrease in cholesterol level compared to baseline, and five patients had $<150 \mathrm{mg} / \mathrm{dL}$ cholesterol level during the examination. Four mild-moderate COVID-19 survivors had cholesterol levels that were greater than $150 \mathrm{mg} / \mathrm{dL}$ at the first examination and did not decrease during the evaluation. Cholesterol is thought to play an important role in the pathological development of COVID-19, and it is associated with severity and mortality, which requires further studies.

Keywords: cholesterol, COVID-19, severity, mortality
\end{abstract}

\section{INTRODUCTION}

Coronavirus Disease 2019 (COVID19) is an infectious disease caused by Severe Acute Respiratory Syndrome Coronavirus 2 (SARS-CoV-2). ${ }^{1}$ SARS-CoV-2 is a new type of Coronavirus that has never been identified previously in humans. At least two Coronavirus strains have been linked to severe symptoms, such as Middle
East Respiratory Syndrome (MERS) and Severe Acute Respiratory Syndrome (SARS). COVID-19 patients can be asymptomatic or symptomatic, with symptoms ranging from mild to severe to critical. Acute respiratory disease syndromes, such as fever, cough, and shortness of breath, are common signs and symptoms of COVID-19. The average 
incubation period is 5-9 days, with the longest incubation time being 14 days. ${ }^{2}$

Severe cases of COVID-19 may cause pneumonia, acute respiratory syndrome, septic shock, multiple organ dysfunction/failure, and even mortality. ${ }^{3}$ This disease started with the emergence of pneumonia cases of unknown etiology in Wuhan, China, at the end of December 2019. On Mar 11, 2020, WHO stated that COVID-19 is a pandemic. ${ }^{4,5}$

Coronavirus is a single-strain positive RNA virus that is encapsulated and not segmented. There are four structures of the main protein in Coronavirus; they are protein N (nucleocapsid), glycoprotein $\mathrm{M}$ (membrane), glycoprotein spike $S$ (S spike), protein E (envelope). Coronavirus belongs to the order Nidovirales, family Coronaviridae. ${ }^{1,6}$

This Coronavirus may cause diseases to animals or humans. There are four genera: alpha coronavirus, beta coronavirus, gamma coronavirus, and delta coronavirus. Before the presence of COVID-19, there are 6 types of coronavirus that can infect human, they are HCoV-229E (alpha coronavirus), HCoV-OC43 (beta coronavirus), HCoVNL63 (alpha coronavirus), HCoV-HKU1 (beta coronavirus), SARS-CoV (beta coronavirus), and MERS-CoV (beta coronavirus. ${ }^{1,6}$

The Coronavirus that becomes the etiology of COVID-19 belongs to the genus beta coronavirus. Generally, it has a round shape with a pleomorphic diameter of 60 $140 \mathrm{~nm}$. The result of the phylogenetic analysis shows that this virus is included in a similar subgenus with the coronavirus that causes the SARS epidemic in 20022004, Sarbecovirus. 79\% RNA sequence is similar to SARS-COV, and $50 \%$ resembles MERS-COV. Based on this data, the International Committee on Taxonomy of Viruses (ICTV) names the cause of COVID19 as SARS-CoV-2. ${ }^{1,7,8}$

Dyslipidemia that is associated with SARS patients has been reported, although it rarely occurs. Some case reports show lower cholesterol levels when it is being compared to healthy subjects. ${ }^{9}$ Other studies reported a lipid metabolism disorder in SARS patients who had been recovered after 12 years of infection. ${ }^{10}$

Based on this study, it is presumed that dyslipidemia may occur in patients with COVID-19. Doctors and researchers, on the other hand, haven't paid much attention to this problem yet. A study reported dyslipidemia in COVID-19 patients, and it demonstrated the relationship between lower cholesterol levels and severity and mortality. ${ }^{11}$

Cases of hypolipidemia show a positive correlation to the severity level of COVID-19. ${ }^{9}$ This case study will describe the cholesterol levels of 21 COVID-19 patients in relation to their severity and survival.

\section{CASE ILLUSTRATIONS}

Ulin Regional Hospital Banjarmasin has treated COVID-19 patients since Mar 14, 2020, and up to Aug 8, 2020, the hospital has treated 442 confirmed COVID19 patients. There are various severities of 
COVID-19 in which they are treated with different laboratory characteristics according to the severity level. There is a phenomenon in confirmed COVID-19 patients without symptoms/mild-moderate symptoms with higher lipid profile levels compared to COVID-19 patients with severe/critical symptoms and non-survival. Below are the descriptions of some cases.

\section{Case 1}

A woman, 29 years old, full-term pregnant with mild COVID-19, was referred to Ulin Regional Hospital, Banjarmasin for a cesarean section surgery. The patient complained of fever and cough. Body mass index (BMI) was $23.2 \mathrm{~kg} / \mathrm{m}^{2}$, and blood pressure was $113 / 92 \mathrm{mmHg}$. There was no abnormality in the physical lung examination. Chest x-ray was within normal limit.

Result from laboratory test was random blood sugar (RBS) $89 \mathrm{mg} / \mathrm{dl}$, neutrophil-lymphocyte ratio (NLR) 4.02\%, absolute lymphocyte count (ALC) 1200/ul, C-reactive protein (CRP) $<6 \mathrm{mg} / \mathrm{L}$, lactate dehydrogenase (LDH) $455 \mathrm{U} / \mathrm{L}$, Ferritin 271 $\mathrm{ng} / \mathrm{mL}$, D-dimer $1.16 \mathrm{mg} / \mathrm{L}$, aspartate aminotransferase (AST) $41 \mathrm{U} / \mathrm{L}$, alanine aminotransferase (ALT) $26 \mathrm{U} / \mathrm{L}$, Cholesterol $281 \mathrm{mg} / \mathrm{dL}$, Triglyceride $218 \mathrm{mg} / \mathrm{dL}$, low density lipoprotein (LDL) $215 \mathrm{mg} / \mathrm{dL}$, and high density lipoprotein (HDL) $49 \mathrm{mg} / \mathrm{dL}$ The patient recovered after 43 days of hospitalization.

\section{Case 2}

A woman, 30 years old, full-term pregnant with asymptomatic COVID-19, was referred to Ulin General Hospital, Banjarmasin, for a cesarean section surgery. BMI was $28.9 \mathrm{~kg} / \mathrm{m}^{2}$, and blood pressure was $120 / 80 \mathrm{mmHg}$. There was no abnormality in the physical lung examination. Chest x-ray was within normal limit. Result from laboratory test was RBS $107 \mathrm{mg} / \mathrm{dl}$, NLR 2.6\%, ALC 2650/ul, CRP 9.2 mg/L, LDH 184 U/L, Ferritin $39.28 \mathrm{ng} / \mathrm{mL}$, D-dimer $0.46 \mathrm{mg} / \mathrm{L}$, AST $15 \mathrm{U} / \mathrm{L}$, ALT $13 \mathrm{U} / \mathrm{L}$, Cholesterol 225 $\mathrm{mg} / \mathrm{dL}$, Triglyceride $218 \mathrm{mg} / \mathrm{dL}$, LDL 172 $\mathrm{mg} / \mathrm{dL}$, and HDL $47 \mathrm{mg} / \mathrm{dL}$. The patient recovered after 38 days of hospitalization.

\section{Case 3}

A woman, 36 years old, full-term pregnant with moderate COVID-19, was referred to Ulin Regional Hospital, Banjarmasin, for a cesarean section surgery. Coughing was reported by the patient.BMI was $28.3 \mathrm{~kg} / \mathrm{m}^{2}$, and blood pressure was $130 / 80 \mathrm{mmHg}$. Rhonchi were heard in the right lower lobe during auscultation. Chest x-rays showed basal right pulmonary infiltrate. Result from laboratory test was RBS $93 \mathrm{mg} / \mathrm{dl}, \mathrm{NLR}$ 2.25\%, ALC 2360/ul, CRP 31.4 mg/L, LDH $507 \mathrm{U} / \mathrm{L}$, Ferritin $370.83 \mathrm{ng} / \mathrm{mL}$, D-dimer $5.08 \mathrm{mg} / \mathrm{L}$, AST $14 \mathrm{U} / \mathrm{L}$, ALT $10 \mathrm{U} / \mathrm{L}$, Cholesterol $274 \mathrm{mg} / \mathrm{dL}$, Triglyceride 214 $\mathrm{mg} / \mathrm{dL}$, LDL $218 \mathrm{mg} / \mathrm{dL}$, and HDL 40 $\mathrm{mg} / \mathrm{dL}$. The patient recovered after 32 days of hospitalization.

\section{Case 4}

A woman, 27 years old, full-term pregnant with asymptomatic COVID-19, was referred to Ulin Regional Hospital 
Banjarmasin for a cesarean section surgery. BMI was $27.8 \mathrm{~kg} / \mathrm{m}^{2}$, and blood pressure was $100 / 75 \mathrm{mmHg}$. There was no abnormality in the physical lung examination. Chest $\mathrm{x}$-ray was within normal limit. Laboratory test result was RBS 79 mg/dl, NLR 3.13\%, ALC 2600/ul, CRP $22.1 \mathrm{mg} / \mathrm{L}$, LDH $242 \mathrm{U} / \mathrm{L}$, Ferritin 29.85 $\mathrm{ng} / \mathrm{mL}$, D-dimer $6.74 \mathrm{mg} / \mathrm{L}$, AST $12 \mathrm{U} / \mathrm{L}$, ALT $11 \mathrm{U} / \mathrm{L}$, Cholesterol $236 \mathrm{mg} / \mathrm{dL}$, Triglyceride $165 \mathrm{mg} / \mathrm{dL}$, LDL $187 \mathrm{mg} / \mathrm{dL}$, and HDL $43 \mathrm{mg} / \mathrm{dL}$. The patient was sent to a halfway house in stable condition after being treated for 18 days.

\section{Case 5}

A 22-year-old female with full-term pregnancy and asymptomatic COVID-19 was referred to Ulin Regional Hospital Banjarmasin for cesarean section surgery. BMI was $21 \mathrm{~kg} / \mathrm{m}^{2}$, and blood pressure was $110 / 70 \mathrm{mmHg}$. There was no abnormality in the physical lung examination. Chest $x$ ray was within normal limit. Laboratory test result was RBS 116 mg/dl, NLR 3.16\%, ALC 1657/ul, CRP $4.2 \mathrm{mg} / \mathrm{L}$, LDH $181 \mathrm{U} / \mathrm{L}$, Ferritin $22.20 \mathrm{ng} / \mathrm{mL}$, D-dimer $6.63 \mathrm{mg} / \mathrm{L}$, AST 25 U/L, ALT 11 U/L, Cholesterol 263 $\mathrm{mg} / \mathrm{dL}$, Triglyceride $114 \mathrm{mg} / \mathrm{dL}$, LDL 244 $\mathrm{mg} / \mathrm{dL}$, and HDL $38 \mathrm{mg} / \mathrm{dL}$. The patient was declared cured after 27 days of treatment.

\section{Case 6}

A 54-year-old female with severe COVID-19, Chronic Kidney Disease (CKD) on regular dialysis, hypertension, and type 2 diabetes deteriorated on the $32^{\text {nd }}$ day of treatment. Shortness of breath, cough, and fever were among the symptoms reported upon admission to the hospital. BMI was 24 $\mathrm{kg} / \mathrm{m}^{2}$, and blood pressure was 169/90 $\mathrm{mmHg}$. There were bilateral basal rhonchi in physical lung examination. Basal right pulmonary infiltrates and cardiomegaly were shown on the chest radiograph.

Result of laboratory test was RBS 211 $\mathrm{mg} / \mathrm{dL}$, NLR 37.5\%, ALC 605/ul, CRP 35.1 $\mathrm{mg} / \mathrm{L}$, LDH $885 \mathrm{U} / \mathrm{L}$, Ferritin 2433.72 $\mathrm{ng} / \mathrm{mL}$, D-dimer $4.86 \mathrm{mg} / \mathrm{L}$, AST $14 \mathrm{U} / \mathrm{L}$, ALT $6 \mathrm{U} / \mathrm{L}$, Cholesterol $191 \mathrm{mg} / \mathrm{dL}$, Triglyceride $194 \mathrm{mg} / \mathrm{dL}$, LDL $127 \mathrm{mg} / \mathrm{dL}$, and HDL $25 \mathrm{mg} / \mathrm{dL}$. The patient's lipid profile was examined again two weeks later, and a significant decrease was found. Cholesterol $73 \mathrm{mg} / \mathrm{dL}$, Triglyceride 62 $\mathrm{mg} / \mathrm{dL}$, LDL $35 \mathrm{mg} / \mathrm{dL}$, and HDL $16 \mathrm{mg} / \mathrm{dL}$. The patient passed away after 34 days of treatment.

\section{Case 7}

A 42-year-old male with critical COVID-19, CKD on dialysis, heart failure, and hypertension. Shortness of breath, fever, cough, and nausea-vomitus were all mentioned by the patient. BMI was 22.91 $\mathrm{kg} / \mathrm{m}^{2}$, and blood pressure was $160 / 106$ $\mathrm{mmHg}$. There were rhonchi in all fields of the lungs during auscultation. Chest radiograph showed bilateral infiltrates on all lobes and cardiomegaly.

Result of laboratory test was RBS 138 $\mathrm{mg} / \mathrm{dL}$, NLR 39.8\%, ALC 319.2/ul, CRP 78.8 mg/L, LDH 1356 U/L, Ferritin >2000 $\mathrm{ng} / \mathrm{mL}$, D-dimer $5.56 \mathrm{mg} / \mathrm{L}$, AST $59 \mathrm{U} / \mathrm{L}$, ALT $14 \mathrm{U} / \mathrm{L}$, Cholesterol $126 \mathrm{mg} / \mathrm{dL}$, Triglyceride $94 \mathrm{mg} / \mathrm{dL}$, LDL $80 \mathrm{mg} / \mathrm{dL}$, and HDL $30 \mathrm{mg} / \mathrm{dL}$. After nine days, the lipid 
profile was reevaluated and found, Cholesterol $90 \mathrm{mg} / \mathrm{dL}$, Triglyceride 186 $\mathrm{mg} / \mathrm{dL}$, LDL $35 \mathrm{mg} / \mathrm{dL}$, and HDL $9 \mathrm{mg} / \mathrm{dL}$. The patient passed away after 14 days of treatment.

\section{Case 8}

A 58-year-old male with critical COVID-19, hypertension, and type 2 diabetes complained of shortness of breath, fever, cough, and sore throat.BMI was $25.3 \mathrm{~kg} / \mathrm{m}^{2}$, and blood pressure was $123 / 79 \mathrm{mmHg}$. Rhonchi were audible on both lungs during auscultation. Chest radiograph showed bilateral infiltrates on all lobes. Laboratory test result was RBS 416 mg/dL, NLR 23.3\%, ALC 630/ul, CRP 278 mg/L, LDH 1446 U/L, Ferritin 4470.10 $\mathrm{ng} / \mathrm{mL}$, no data of D-dimer, AST $74 \mathrm{U} / \mathrm{L}$, ALT $98 \mathrm{U} / \mathrm{L}$, Cholesterol $145 \mathrm{mg} / \mathrm{dL}$, Triglyceride $195 \mathrm{mg} / \mathrm{dL}$, LDL $94 \mathrm{mg} / \mathrm{dL}$, and HDL $19 \mathrm{mg} / \mathrm{dL}$. The patient passed away after four days of treatment.

\section{Case 9}

An overweight, 47-year-old male with critical COVID-19 complained shortness of breath, cough, sore throat, and nausea upon hospital admission. BMI was 28.9 $\mathrm{kg} / \mathrm{m}^{2}$, and blood pressure was $123 / 71$ $\mathrm{mmHg}$. There were rhonchi in the right lung medial basal and left lung basal in physical lung examination. The chest $x$-ray showed infiltrates in all right lobes and middle-lower left lobes. Result of laboratory test was RBS $88 \mathrm{mg} / \mathrm{dL}$, NLR 6.14\%, ALC 1830/ul, CRP 194.6 mg/L, LDH $1056 \mathrm{U} / \mathrm{L}$, Ferritin >2000 ng/mL, D-dimer $0.91 \mathrm{mg} / \mathrm{L}$, AST $108 \mathrm{U} / \mathrm{L}$, ALT $58 \mathrm{U} / \mathrm{L}$,
Cholesterol 136 mg/dL, Triglyceride 178 $\mathrm{mg} / \mathrm{dL}$, LDL $104 \mathrm{mg} / \mathrm{dL}$, and HDL 20 $\mathrm{mg} / \mathrm{dL}$. The patient passed away after five days of treatment.

\section{Case 10}

A 68-year-old male with hypertension and type 2 diabetes was diagnosed with critical COVID-19. Shortness of breath, fever, cough, and nausea were noted upon admission. BMI was $23.4 \mathrm{~kg} / \mathrm{m}^{2}$, and blood pressure was $139 / 90 \mathrm{mmHg}$. There were rhonchi in both middle-lower lobes in physical lung examination. There were bilateral peripheral infiltrates on chest radiograph. Laboratory test result was RBS 166 mg/dL, NLR 11.1\%, ALC 751/ul, CRP 200.8 mg/L, LDH 591 U/L, Ferritin 555.63 $\mathrm{ng} / \mathrm{mL}$, no data of D-dimer, AST $50 \mathrm{U} / \mathrm{L}$, ALT $35 \mathrm{U} / \mathrm{L}$, Cholesterol $138 \mathrm{mg} / \mathrm{dL}$, Triglyceride $168 \mathrm{mg} / \mathrm{dL}$, LDL $83 \mathrm{mg} / \mathrm{dL}$, and HDL $21 \mathrm{mg} / \mathrm{dL}$. The patient passed away after three days of treatment.

\section{Case 11}

A 65-year-old woman with moderate COVID-19. The patient had hypertension, heart failure, and was overweight. She had a fever and a cough. During the course of treatment, the patient's condition deteriorated. BMI was $27.1 \mathrm{~kg} / \mathrm{m}^{2}$, and blood pressure was $130 / 81 \mathrm{mmHg}$. There were no rhonchi in the initial lung examination, but rhonchi were found in both lung fields during treatment. There was no infiltrate on the initial chest $x$-ray, but on chest $x$-ray evaluation, there were bilateral peripheral infiltrates. 
Result of laboratory test was RBS 99 $\mathrm{mg} / \mathrm{dL}$, NLR 1.7\%, ALC 1782/ul, CRP 32 $\mathrm{mg} / \mathrm{L}, \mathrm{LDH} 528 \mathrm{U} / \mathrm{L}$, Ferritin $>2000 \mathrm{ng} / \mathrm{mL}$, D-dimer 1.23 mg/L, AST $139 \mathrm{U} / \mathrm{L}$, ALT 87 $\mathrm{U} / \mathrm{L}$, Cholesterol $112 \mathrm{mg} / \mathrm{dL}$, Triglyceride $148 \mathrm{mg} / \mathrm{dL}$, LDL $74 \mathrm{mg} / \mathrm{dL}$, and HDL 25 $\mathrm{mg} / \mathrm{dL}$. Six days later, laboratory evaluation was conducted, and the result was NLR 5.63\%, ALC 1250/ul, CRP 229.9 mg/L, LDH $944 \mathrm{U} / \mathrm{L}$, Ferritin $5505.42 \mathrm{ng} / \mathrm{mL}$, D-dimer $5.10 \mathrm{mg} / \mathrm{L}$, AST $129 \mathrm{U} / \mathrm{L}$, ALT $115 \mathrm{U} / \mathrm{L}$, Cholesterol $139 \mathrm{mg} / \mathrm{dL}$, Triglyceride 180 $\mathrm{mg} / \mathrm{dL}$, LDL $67 \mathrm{mg} / \mathrm{dL}$, and HDL $26 \mathrm{mg} / \mathrm{dL}$. The patient passed away after 14 days of treatment.

\section{Case 12}

A 53-year-old male with a history of spondylitis TB was admitted to the hospital with diarrhea, nausea, and vomit. He was diagnosed with mild-COVID-19. BMI was $18.7 \mathrm{~kg} / \mathrm{m}^{2}$, and blood pressure was $105 / 88 \mathrm{mmHg}$. There was no abnormality from the physical lung examination. Chest $x$-ray was within normal limit.

Result of laboratory test was RBS 178 mg/dL, NLR 6.68\%, ALC 1218/ul, CRP 38.6 mg/L, LDH 604 U/L, Ferritin 1969.52 $\mathrm{ng} / \mathrm{mL}$, D-dimer $2.48 \mathrm{mg} / \mathrm{L}$, AST $20 \mathrm{U} / \mathrm{L}$, ALT $44 \mathrm{U} / \mathrm{L}$, Cholesterol $189 \mathrm{mg} / \mathrm{dL}$, Triglyceride $171 \mathrm{mg} / \mathrm{dL}$, LDL $158 \mathrm{mg} / \mathrm{dL}$, and HDL $23 \mathrm{mg} / \mathrm{dL}$. Laboratory evaluation was done two weeks later, and the result was NLR 3.94\%, ALC 1070/ul, CRP 8 mg/L, LDH $144 \mathrm{U} / \mathrm{L}$, Ferritin 804.64 ng/mL, Ddimer $0.96 \mathrm{mg} / \mathrm{L}$, AST $12 \mathrm{U} / \mathrm{L}$, ALT $14 \mathrm{U} / \mathrm{L}$, Cholesterol $173 \mathrm{mg} / \mathrm{dL}$, Triglyceride 218 mg/dL, LDL $143 \mathrm{mg} / \mathrm{dL}$, and HDL 26 $\mathrm{mg} / \mathrm{dL}$. The patient was discharged after 20 days of hospitalization.

\section{Case 13}

An overweight, 33-year-old male was diagnosed with critical COVID-19.He complained of shortness of breath, fever, cough, and nausea. BMI was $28.7 \mathrm{~kg} / \mathrm{m}^{2}$, and blood pressure was 112/80 $\mathrm{mmHg}$. There were rhonchi at the base of both lungs from auscultation. Chest CT showed peripheral opacity glass ground with consolidation $>3 \mathrm{~cm}$ multifocal in the right and left superior-inferior lobes.

Result from laboratory test was RBS $118 \mathrm{mg} / \mathrm{dL}$, NLR 10.5\%, ALC 448/ul, CRP 171.6 mg/L, LDH 397 U/L, Ferritin >2000 $\mathrm{ng} / \mathrm{mL}$, D-dimer $1.77 \mathrm{mg} / \mathrm{L}$, AST $51 \mathrm{U} / \mathrm{L}$, ALT $50 \mathrm{U} / \mathrm{L}$, Cholesterol $146 \mathrm{mg} / \mathrm{dL}$, Triglyceride $81 \mathrm{mg} / \mathrm{dL}$, LDL $115 \mathrm{mg} / \mathrm{dL}$, and HDL 34 mg/dL. Two weeks later, laboratory evaluation was conducted, and the result was NLR 3.57\%, ALC 1000/ul, CRP 6.1 $\mathrm{mg} / \mathrm{L}$, LDH $251 \mathrm{U} / \mathrm{L}$, Ferritin 1126.41 $\mathrm{ng} / \mathrm{mL}$, D-dimer $1.19 \mathrm{mg} / \mathrm{L}$, AST $92 \mathrm{U} / \mathrm{L}$, ALT $216 \mathrm{U} / \mathrm{L}$, Cholesterol $162 \mathrm{mg} / \mathrm{dL}$, Triglyceride $91 \mathrm{mg} / \mathrm{dL}, \mathrm{LDL} 136 \mathrm{mg} / \mathrm{dL}$, and HDL $37 \mathrm{mg} / \mathrm{dL}$. The patient was treated for 23 days, and was discharged for selfisolation.

\section{Case 14}

A 60-year-old male smoker with hypertension and pulmonary TB was admitted for critical COVID-19. He complained of shortness of breath, fever, and cough. BMI was $20.8 \mathrm{~kg} / \mathrm{m}^{2}$, and blood pressure was $141 / 100 \mathrm{mmHg}$. There were rhonchi in the right middle-lower lobes and 
all left lobes from the physical lung examination. The chest $\mathrm{x}$-ray showed infiltrates in both lungs, predominantly left.

Result of laboratory test was RBS 112 $\mathrm{mg} / \mathrm{dL}$, NLR 8.5\%, ALC 1330/ul, CRP 218.6 mg/L, LDH $1250 \mathrm{U} / \mathrm{L}$, Ferritin 2568.08 $\mathrm{ng} / \mathrm{mL}$, D-dimer $5.40 \mathrm{mg} / \mathrm{L}$, AST $207 \mathrm{U} / \mathrm{L}$, ALT $181 \mathrm{U} / \mathrm{L}$, Cholesterol $236 \mathrm{mg} / \mathrm{dL}$, Triglyceride $105 \mathrm{mg} / \mathrm{dL}$, LDL $233 \mathrm{mg} / \mathrm{dL}$, and $\mathrm{HDL} 30 \mathrm{mg} / \mathrm{dL}$. Three weeks later laboratory evaluation was conducted, and the result was NLR 24.67\%, ALC 520/ul, CRP $78.8 \mathrm{mg} / \mathrm{L}$, LDH $246 \mathrm{U} / \mathrm{L}$, Ferritin $3359.02 \mathrm{ng} / \mathrm{mL}$, D-dimer $4.83 \mathrm{mg} / \mathrm{L}$, AST $45 \mathrm{U} / \mathrm{L}$, ALT $93 \mathrm{U} / \mathrm{L}$, Cholesterol $164 \mathrm{mg} / \mathrm{dL}$, Triglyceride $112 \mathrm{mg} / \mathrm{dL}$, LDL $133 \mathrm{mg} / \mathrm{dL}$, and HDL $39 \mathrm{mg} / \mathrm{dL}$. The patient was discharged after 57 days of treatment.

\section{Case 15}

A 60-year-old male with history of stroke, hypertension, and CKD was taken to the hospital after an episode of seizure, shortness of breath, fever, cough, nausea, and vomit. He was diagnosed with moderate COVID-19. BMI was $25.6 \mathrm{~kg} / \mathrm{m}^{2}$, and blood pressure was $157 / 89 \mathrm{mmHg}$. No abnormality were found in the lung examination. The chest radiograph showed minimal infiltrates at the base of the right lung.

Laboratory result showed that RBS was $111 \mathrm{mg} / \mathrm{dL}$, NLR 14.3\%, ALC 1090/ul, CRP 357 mg/L, LDH $317 \mathrm{U} / \mathrm{L}$, Ferritin $>2000$ ng/mL, D-dimer 5.16 mg/L, AST 37 $\mathrm{U} / \mathrm{L}$, ALT $9 \mathrm{U} / \mathrm{L}$, Cholesterol $96 \mathrm{mg} / \mathrm{dL}$, Triglyceride $77 \mathrm{mg} / \mathrm{dL}$, LDL $72 \mathrm{mg} / \mathrm{dL}$, and HDL $16 \mathrm{mg} / \mathrm{dL}$. Blood work reevaluation result were NLR 1.98\%, ALC 1420/ul, CRP
253.7 mg/L, LDH 144 U/L, Ferritin 2834.89 $\mathrm{ng} / \mathrm{mL}$, D-dimer $2.76 \mathrm{mg} / \mathrm{L}$, AST $17 \mathrm{U} / \mathrm{L}$, ALT $9 \mathrm{U} / \mathrm{L}$, Cholesterol $180 \mathrm{mg} / \mathrm{dL}$, Triglyceride $109 \mathrm{mg} / \mathrm{dL}$, LDL $162 \mathrm{mg} / \mathrm{dL}$, and HDL $26 \mathrm{mg} / \mathrm{dL}$. The patient was discharged after 47 days of treatment.

\section{Case 16}

A 47-year-old female with hypertension and CKD came with shortness of breath and cough, and was diagnosed with moderate COVID-19. BMI was 22.9 $\mathrm{kg} / \mathrm{m}^{2}$, and blood pressure was $161 / 100$ $\mathrm{mmHg}$. From auscultation, there were rhonchi in both middle-lower lobes. The chest $\mathrm{x}$-ray showed bilateral infiltrates in both middle-lower lobes.

Result of laboratory test was RBS 88 $\mathrm{mg} / \mathrm{dL}$, NLR 11.19\%, ALC 660/ul, CRP 32 mg/L, LDH 395 U/L, Ferritin 2128,73 ng/mL, D-dimer 5.8 mg/L, AST 25 U/L, ALT $34 \mathrm{U} / \mathrm{L}$, Cholesterol $162 \mathrm{mg} / \mathrm{dL}$, Triglyceride $88 \mathrm{mg} / \mathrm{dL}$, LDL $112 \mathrm{mg} / \mathrm{dL}$, and HDL 39 $\mathrm{mg} / \mathrm{dL}$. Laboratory evaluation was conducted five weeks later, and the result was NLR 36.48\%, ALC 560/ul, CRP 4.7 $\mathrm{mg} / \mathrm{L}$, LDH $306 \mathrm{U} / \mathrm{L}$, Ferritin 4889.89 $\mathrm{ng} / \mathrm{mL}$, D-dimer $4.83 \mathrm{mg} / \mathrm{L}$, AST $13 \mathrm{U} / \mathrm{L}$, ALT $31 \mathrm{U} / \mathrm{L}$, Cholesterol $174 \mathrm{mg} / \mathrm{dL}$, Triglyceride $189 \mathrm{mg} / \mathrm{dL}$, LDL $85 \mathrm{mg} / \mathrm{dL}$, and HDL $51 \mathrm{mg} / \mathrm{dL}$. The patient was discharged after 37 days of hospitalization.

\section{Case 17}

A 58-year-old female with a history of acute lymphoblastic leukemia (ALL) type L1 and hypertension came with shortness of breath, cough, and sore throat, and was diagnosed with moderate COVID-19. BMI 
was $18.1 \mathrm{~kg} / \mathrm{m}^{2}$, and blood pressure was $158 / 100 \mathrm{mmHg}$. Rhonchi at the base of the right lung was heard during auscultation. The chest $x$-ray showed infiltrates in both lung bases.

Result of laboratory test was RBS 145 mg/dL, NLR 5.59\%, ALC 240/ul, CRP 116.5 $\mathrm{mg} / \mathrm{L}$, LDH $810 \mathrm{U} / \mathrm{L}$, Ferritin 2910.37 $\mathrm{ng} / \mathrm{mL}$, D-dimer $4.85 \mathrm{mg} / \mathrm{L}$, AST $16 \mathrm{U} / \mathrm{L}$, ALT $32 \mathrm{U} / \mathrm{L}$, Cholesterol $234 \mathrm{mg} / \mathrm{dL}$, Triglyceride $132 \mathrm{mg} / \mathrm{dL}$, LDL $141 \mathrm{mg} / \mathrm{dL}$, and HDL $37 \mathrm{mg} / \mathrm{dL}$. Four weeks later there was laboratory evaluation, and the result was NLR 3.66\%, ALC 4192.5/ul, CRP 15.7 $\mathrm{mg} / \mathrm{L}$, LDH $254 \mathrm{U} / \mathrm{L}$, Ferritin 2111.74 $\mathrm{ng} / \mathrm{mL}$, D-dimer $3.89 \mathrm{mg} / \mathrm{L}$, AST $18 \mathrm{U} / \mathrm{L}$, ALT $10 \mathrm{U} / \mathrm{L}$, Cholesterol $167 \mathrm{mg} / \mathrm{dL}$, Triglyceride $169 \mathrm{mg} / \mathrm{dL}$, LDL $124 \mathrm{mg} / \mathrm{dL}$, and HDL $33 \mathrm{mg} / \mathrm{dL}$ Patient was discharged after 37 days of treatment.

\section{Case 18}

A 51-year-old female with a history of CKD and hypertension complained of shortness of breath and cough. She was diagnosed with moderate COVID-19. BMI was $19.9 \mathrm{~kg} / \mathrm{m}^{2}$, and blood pressure was $169 / 72 \mathrm{mmHg}$. Rhonchi were audible at the base of the lungs and chest radiograph showed infiltrates in the right middle-lower lobes and cardiomegaly. $\mathrm{R}$

esult of laboratory test was RBS 96 $\mathrm{mg} / \mathrm{dL}$, NLR 8.6\%, ALC 1020/ul, CRP 3 $\mathrm{mg} / \mathrm{L}, \mathrm{LDH} 1200 \mathrm{U} / \mathrm{L}$, Ferritin $1215 \mathrm{ng} / \mathrm{mL}$, no data of D-dimer, AST $112 \mathrm{U} / \mathrm{L}$, ALT 66 U/L, Cholesterol $239 \mathrm{mg} / \mathrm{dL}$, Triglyceride $411 \mathrm{mg} / \mathrm{dL}$, LDL $142 \mathrm{mg} / \mathrm{dL}$, and HDL 29 $\mathrm{mg} / \mathrm{dL}$. Two weeks later laboratory evaluation was reevaluated, and the results were NLR 1.74\%, ALC 930/ul, CRP 0.6 $\mathrm{mg} / \mathrm{L}$, LDH $260 \mathrm{U} / \mathrm{L}$, Ferritin $514.0 \mathrm{ng} / \mathrm{mL}$, no data of D-dimer, AST $20 \mathrm{U} / \mathrm{L}, \mathrm{ALT} 11$ $\mathrm{U} / \mathrm{L}$, Cholesterol $177 \mathrm{mg} / \mathrm{dL}$, Triglyceride $148 \mathrm{mg} / \mathrm{dL}$, LDL $127 \mathrm{mg} / \mathrm{dL}$, and HDL 39 $\mathrm{mg} / \mathrm{dL}$. The patient was discharged after 22 days of treatment.

\section{Case 19}

A 61-year-old female with previous history of type 2 diabetes, hypertension, and heart failure complained of shortness of breath and was diagnosed with severe COVID-19. BMI $25.8 \mathrm{~kg} / \mathrm{m}^{2}$ and blood pressure was $153 / 99 \mathrm{mmHg}$. Rhonchi was audible on auscultation especially in the right middle-lower lobes and left lower lobes. Infiltrates were prominent on the right middle-lower lobes and cardiomegaly was visible on chest radiograph.

Result of laboratory test was RBS 272 $\mathrm{mg} / \mathrm{dL}$, NLR 15.22\%, ALC 900/ul, CRP 6.0 $\mathrm{mg} / \mathrm{L}, \mathrm{LDH} 490 \mathrm{U} / \mathrm{L}$, Ferritin $295.71 \mathrm{ng} / \mathrm{mL}$, D-dimer $5.50 \mathrm{mg} / \mathrm{L}$, AST $29 \mathrm{U} / \mathrm{L}$, ALT 25 $\mathrm{U} / \mathrm{L}$, Cholesterol $243 \mathrm{mg} / \mathrm{dL}$, Triglyceride $132 \mathrm{mg} / \mathrm{dL}$, LDL $172 \mathrm{mg} / \mathrm{dL}$, and HDL 68 $\mathrm{mg} / \mathrm{dL}$. Laboratory evaluation was conducted two weeks later and the result was NLR 2.85\%, ALC 1857/ul, CRP 54.4 $\mathrm{mg} / \mathrm{L}$, LDH $239 \mathrm{U} / \mathrm{L}$, Ferritin $569.54 \mathrm{ng} / \mathrm{mL}$, D-dimer 1.66 mg/L, AST $29 \mathrm{U} / \mathrm{L}$, ALT 35 $\mathrm{U} / \mathrm{L}$, Cholesterol $186 \mathrm{mg} / \mathrm{dL}$, Triglyceride $107 \mathrm{mg} / \mathrm{dL}$, LDL $121 \mathrm{mg} / \mathrm{dL}$, and HDL 67 $\mathrm{mg} / \mathrm{dL}$. The patient was discharged after 18 days of treatment.

\section{Case 20}

A 71-year-old male came with shortness of breath, fever, cough, diarrhea, 
nausea and vomit, and was diagnosed with severe COVID-19. BMI was $23.4 \mathrm{~kg} / \mathrm{m}^{2}$, and blood pressure was $138 / 65 \mathrm{mmHg}$. Rhonchi in bilateral medial basal was found from auscultation. Chest x-ray showed infiltrates in both lungs.

Laboratory examination showed that RBS 87 mg/dL, NLR 8.7\%, ALC 646/ul, CRP 207.2 mg/L, LDH 852 U/L, Ferritin 446.88 $\mathrm{ng} / \mathrm{mL}$, D-dimer $4.56 \mathrm{mg} / \mathrm{L}$, AST $63 \mathrm{U} / \mathrm{L}$, ALT $34 \mathrm{U} / \mathrm{L}$, Cholesterol $113 \mathrm{mg} / \mathrm{dL}$, Triglyceride $85 \mathrm{mg} / \mathrm{dL}$, LDL $96 \mathrm{mg} / \mathrm{dL}$, and HDL $17 \mathrm{mg} / \mathrm{dL}$. Four weeks later there was laboratory evaluation, and the result was NLR 3.80\%, ALC 1120/ul, CRP 6.0 mg/L, LDH $213 \mathrm{U} / \mathrm{L}$, Ferritin $208.11 \mathrm{ng} / \mathrm{mL}$, Ddimer $0.70 \mathrm{mg} / \mathrm{L}$, AST $27 \mathrm{U} / \mathrm{L}$, ALT $29 \mathrm{U} / \mathrm{L}$, Cholesterol $156 \mathrm{mg} / \mathrm{dL}$, Triglyceride 124 $\mathrm{mg} / \mathrm{dL}$, LDL $96 \mathrm{mg} / \mathrm{dL}$, and HDL $17 \mathrm{mg} / \mathrm{dL}$. After 43 days of treatment, the patient was discharged.

\section{Case 21}

A 58-year-old male with a history of hypertension was admitted with critical
COVID-19. The patient complained of shortness of breath, fever, cough, diarrhea, epigastric pain, nausea, and vomit. BMI was $27.9 \mathrm{~kg} / \mathrm{m}^{2}$, and blood pressure was $149 / 100 \mathrm{mmHg}$. Rhonchi were audible especially in both middlelower lobes.

Results of chest x-ray showed infiltrates in both lungs. Result of laboratory test was RBS $140 \mathrm{mg} / \mathrm{dL}$, NLR 6.56\%, ALC 960/ul, CRP 59.8 mg/L, LDH $880 \mathrm{U} / \mathrm{L}$, Ferritin $5835.82 \mathrm{ng} / \mathrm{mL}$, D-dimer $1.92 \mathrm{mg} / \mathrm{L}$, AST $92 \mathrm{U} / \mathrm{L}, \mathrm{ALT} 91 \mathrm{U} / \mathrm{L}$, Cholesterol $198 \mathrm{mg} / \mathrm{dL}$, Triglyceride 193 $\mathrm{mg} / \mathrm{dL}$, LDL $112 \mathrm{mg} / \mathrm{dL}$, and HDL 47 $\mathrm{mg} / \mathrm{dL}$. Laboratory evaluation was conducted four weeks later, and the result was NLR 2.0\%, ALC 1725/ul, CRP <0.2 $\mathrm{mg} / \mathrm{L}, \mathrm{LDH} 239 \mathrm{U} / \mathrm{L}$, Ferritin $1272.6 \mathrm{ng} / \mathrm{mL}$, D-dimer 0.44 mg/L, AST $49 \mathrm{U} / \mathrm{L}$, ALT 101 $\mathrm{U} / \mathrm{L}$, Cholesterol $261 \mathrm{mg} / \mathrm{dL}$, Triglyceride $372 \mathrm{mg} / \mathrm{dL}$, LDL $171 \mathrm{mg} / \mathrm{dL}$, and HDL 44 $\mathrm{mg} / \mathrm{dL}$. The patient was discharged after 33 days of hospitalization.

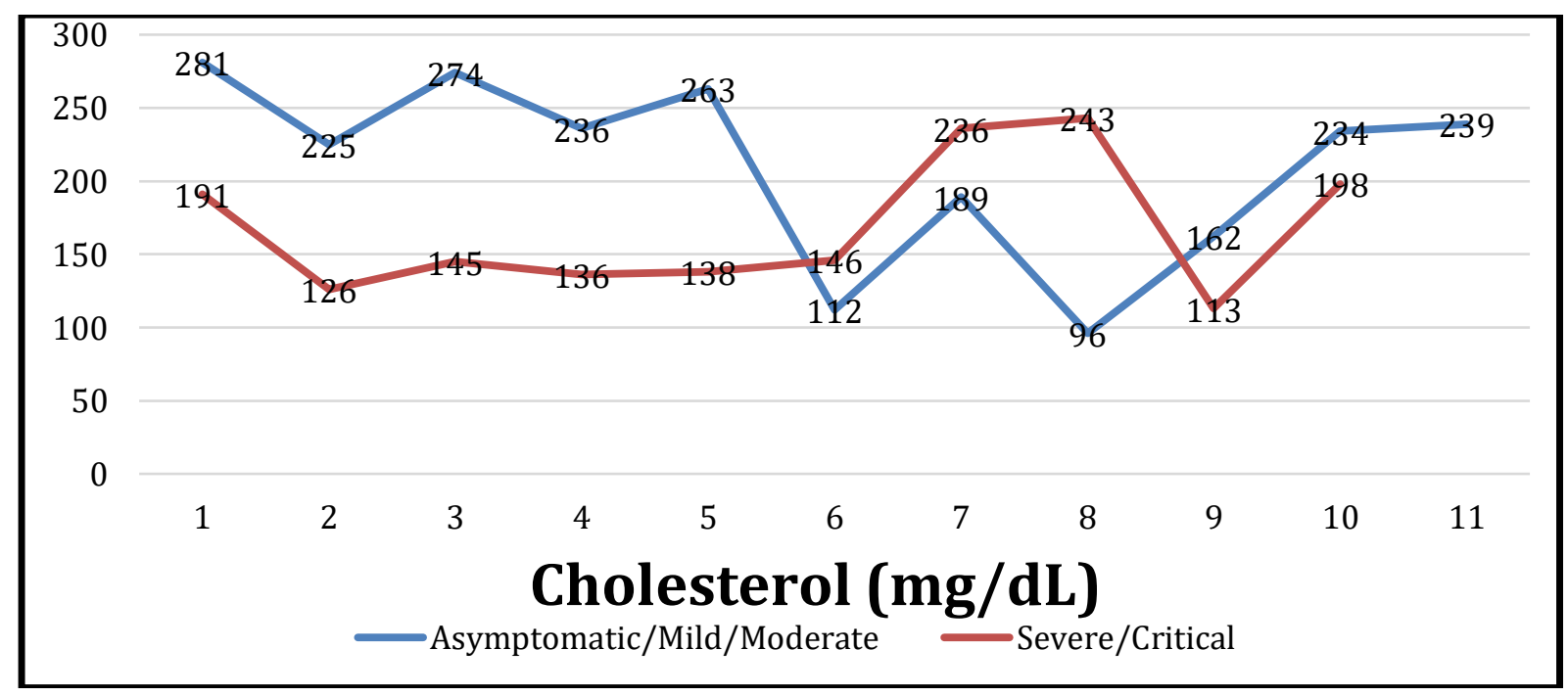

Graphic 1 . Cholesterol level according to the severity of COVID-19 patients 


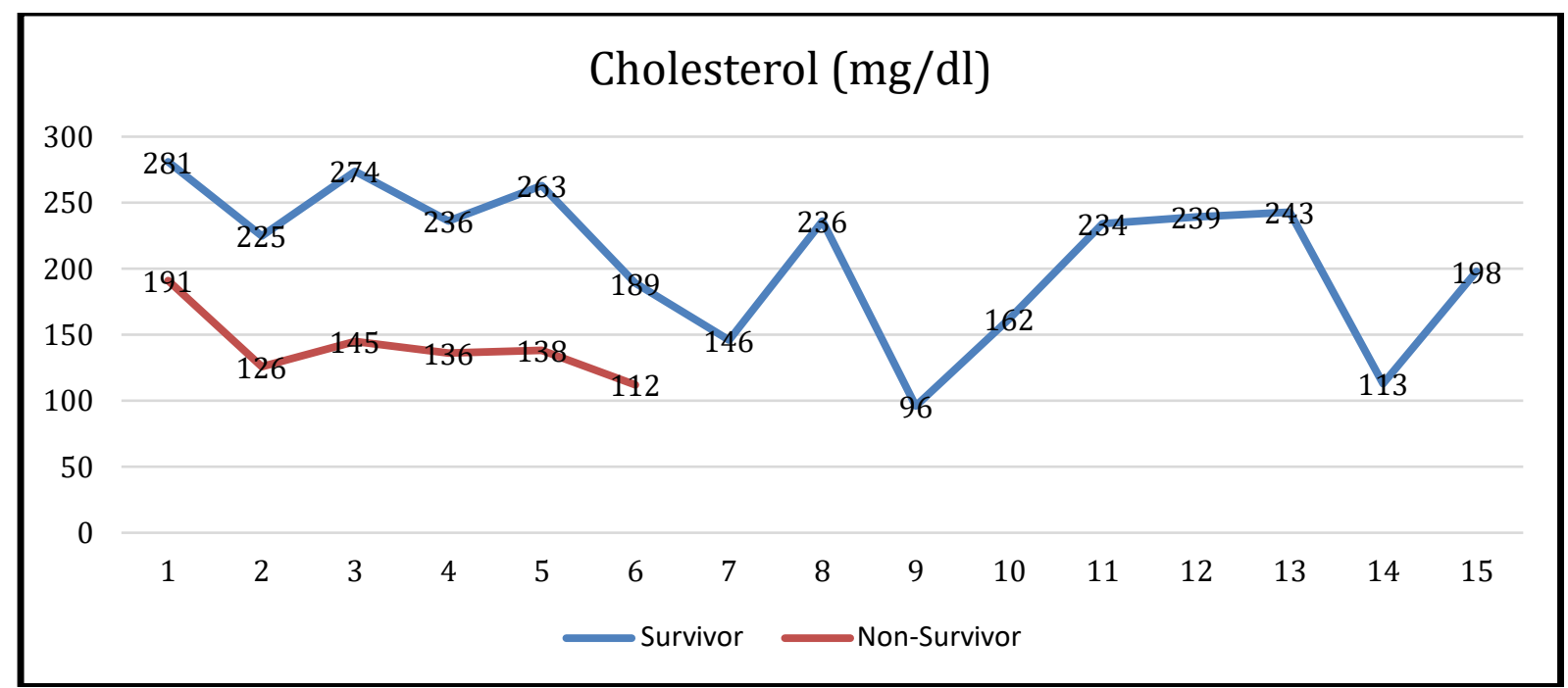

Graphic 2. Cholesterol level in survivor and non-survivor of COVID-19 patients

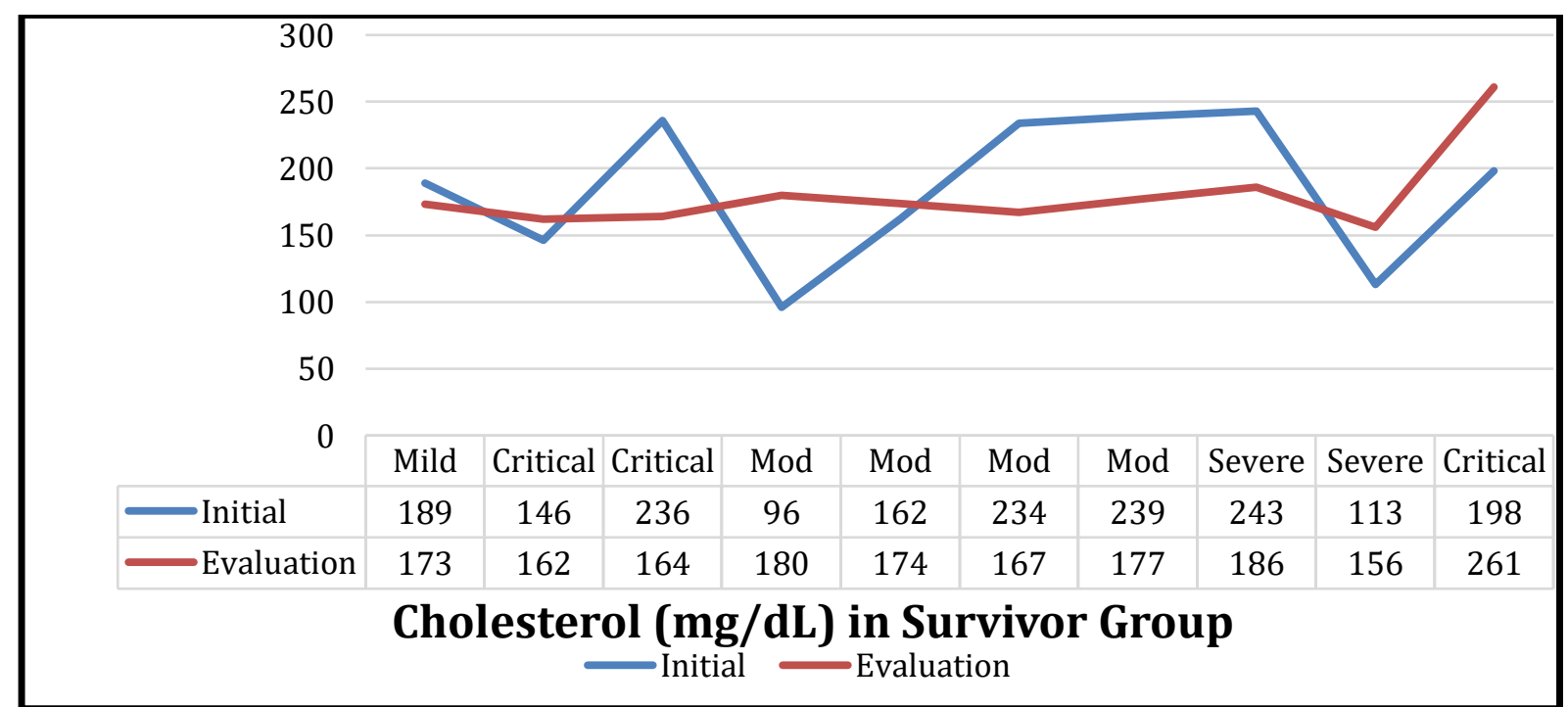

Graphic 3. Cholesterol level in COVID-19 survivors (initial and reevaluation)

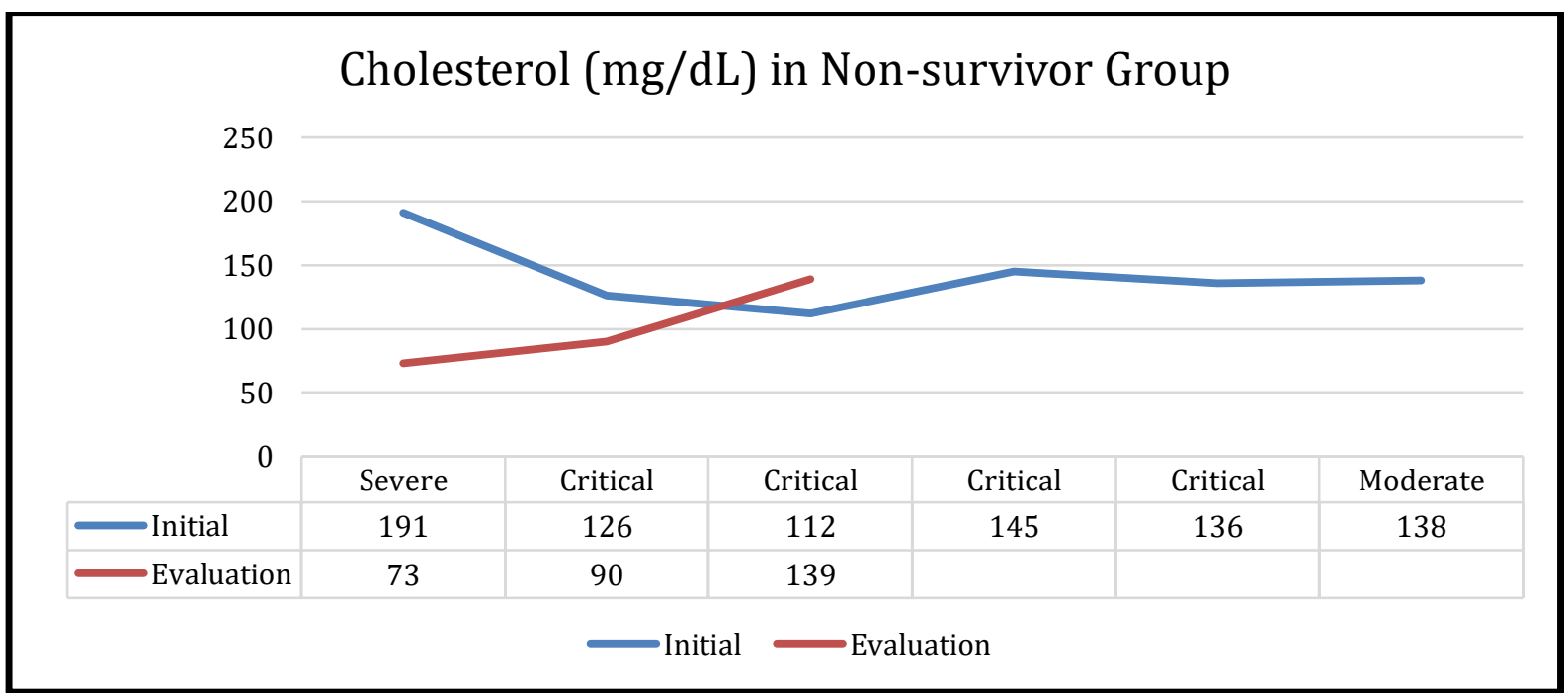

Graphic 4. Cholesterol level in the non-survivor group of COVID-19 patients (initial and reevaluation) 


\section{DISCUSSION}

Recently, dyslipidemia cases were reported in COVID-19 patients, and it shows that cholesterol level decrease is associated with severity level and mortality. ${ }^{4,5}$ In a cohort study of 21 patients, lipid profile was examined before the virus infection and during the disease. The patient's cholesterol level, LDL, and HDL decreased when treated in the hospital, and those levels remain low during the hospitalization. Cholesterol and LDL levels return to the baseline of the outpatients. However, a continuous decrease of those levels occurs in nonsurvivors. ${ }^{5}$

In another cohort study with more samples $(n=597)$, lipid profile data is classified as mild, moderate, severe, or critical.The level of cholesterol and LDL decreased in COVID-19 patients compared to healthy subjects, and the decreased level correlates with the progress of the symptoms. ${ }^{4}$

The possibility of dyslipidemia occurrence in COVID-19 patients because of the side effects of the intervention is very slight as the patient's cholesterol level decreases before the intervention. The patients receive various kinds of medicine during the treatment, and their cholesterol levels improve along with their symptoms. ${ }^{5}$ A study of proteomic and metabolism of COVID-19 patients showed massive suppression of metabolism. It included dysregulation of some apolipoproteins
(Apo), for example, Apo A1, Apo A2, Apo $\mathrm{H}$, Apo L1, Apo D, and Apo M. ${ }^{12}$

Hypolipidemia is a rare illness caused by multifactorial inheritance, including genetic alterations and other secondary factors. Hypolipidemia is frequently asymptomatic and is discovered during a lipid profile screening test. In COVID-19, it was stated that the decrease in lipid levels was most likely the result of SARS-CoV-2 infection with a complex pathological process. Because there is no consented limit for cholesterol levels, it is referred to as hypolipidemia. ${ }^{9}$

The cholesterol level that is mainly used for hypolipidemia is $120-150 \mathrm{mg} / \mathrm{dL}$. Several other studies used the median or cut-off obtained in their research. ${ }^{9,13}$ There are three causes of primary hypolipidemia that rarely occur abetalipoproteinemia, hypobetalipoproteinemia, and chylomicron retention disease. Secondary hypolipidemia occurs more often and may be caused by acute or chronic infection, malabsorption, malnutrition, anemia, critical illness, chronic inflammation, malignancy, hyperthyroidism, chronic liver disease, and the effect of therapy with statin. ${ }^{13,14}$

In acute or chronic bacterial infection, viral infection and parasite infection may cause hypolipidemia/ hypocholesterolemia because of the pro-inflammatory cytokine effect on lipoprotein metabolism. ${ }^{15}$ In 2012, Metwally et al. reported a preliminary report about hypocholesterolemia at the patient with TB. ${ }^{16}$ Since then, hypercholesterolemia is often found during the acute phase of bacterial infection. ${ }^{15}$ 
These changes are mediated by various pro-inflammatory cytokines such as Interleukin (IL)-1, IL-6, and Tumour Necrosis Factor (TNF) alpha involved during the acute phase in sepsis. ${ }^{17}$

For critically ill patients, the decreased cholesterol level marks the presence of infection. A recent crosssectional study demonstrated the importance of lipid changes in sepsis and found low plasma lipid levels but could not determine whether these were pathogenic findings, reflecting more severe severity or higher microbial burden and lipopolysaccharides (LPS) levels. Cholesterol may play a role in host defense in sepsis, as suggested by the observation that circulating lipids and lipoproteins bind to and neutralize endotoxins. ${ }^{18}$

Some researchers believe that hypocholesterolemia is a more sensitive marker of infection presence than leukocytosis. ${ }^{15,19}$ Besides that, hypocholesterolemia is significantly correlated to the acute phase in sepsis in line with CRP level. ${ }^{17}$

Other studies about cholesterol and viral infection also reported, such as hepatitis and dengue infection. Lipid levels are altered in HCV patients, regardless of day infection. In studies in acute HCV patients, LDL and total cholesterol levels were linked to early infection. ${ }^{19,20}$ In Hepatitis B, chronic infection with cirrhosis, $\mathrm{LDL}$, and HDL level decrease seems to happen. ${ }^{21}$ Lima et al. found a decrease in total serum level of cholesterol and LDL in patients with dengue infection. ${ }^{22}$
Several cases above described Pregnant women who were going on cesarean sections with asymptomatic and mild-moderate COVID-19. Laboratory test results show a high level of the lipid profile of the patients. Dyslipidemia is predicted to correlate with the severity level of COVID19 but is a dyslipidemia condition in pregnant women related to the severity of COVID-19. Pregnancy in healthy women occurs when a normal change of fat metabolism benefits fetus growth and development, thus increasing lipid levels. Deposition and maternal adipose hypertrophy occur during the first trimester of pregnancy due to an increase in insulin receptor expression. ${ }^{23}$

The increased maternal insulin, besides progesterone production, causes lipogenesis with reduced lipolysis, lipid production increases which then being transported to the fetus through placenta for fetus growth. This change is generally non-atherogenic, and lipid profile level will decrease to pre-pregnancy level after birth. ${ }^{23}$ Dyslipidemia in pregnancy may risk premature birth, hypertension in pregnancy, preeclampsia, and gestational diabetes. These risks increase in high triglyceride, low HDL, and small dense-high LDL atherogenic fraction. As a result, the risk of cardiovascular disease will increase. ${ }^{24,25}$

Pregnant females with asymptomatic and mild-moderate COVID-19 in this case series were allowed to be discharged, no complications associated with dyslipidemia such as premature birth, hypertension, preeclampsia, and gestational diabetes 
were noted.There is a study about characteristics of the pregnant females with COVID-19 in Wuhan, from 118 pregnant females, 109 of them were mildmoderate $(92 \%)$, and nine were severe to critical $(8 \%){ }^{26}$

No data supports the severity level increase of COVID-19 in pregnant females. ${ }^{3}$ Another study by Zhu et al. reported that clinical manifestations of the pregnant females with confirmed COVID-19 were similar with the non-pregnant females with COVID-19 infection and had relatively good clinical outcomes. ${ }^{27,28}$ Our case series showed no clear relationship between dyslipidemia in pregnant women with the severity of COVID-19.

From the non-survivor group, two patients had a significant decrease in cholesterol level compared to the initial examination. The other five patients had low cholesterol levels ( $<150 \mathrm{mg} / \mathrm{dL}$ ) from the beginning.
In four mild-moderate survivors, initial cholesterol levels were $>150 \mathrm{mg} / \mathrm{dl}$, and there was no decrease until $<150$ $\mathrm{mg} / \mathrm{dl}$. Meanwhile, one moderate COVID19 patient with initial cholesterol $<150$ $\mathrm{mg} / \mathrm{dl}$ increased to $>150 \mathrm{mg} / \mathrm{dl}$. In two survivors with severe/critical infection who had initial cholesterol $<150 \mathrm{mg} / \mathrm{dL}$ and increased during evaluation, while three other patients from the beginning had initial cholesterol above $>150 \mathrm{mg} / \mathrm{dL}$.

Based on this data, cholesterol levels tend to be low in patients with poor prognoses. Non-survivor who already had high levels of cholesterol also experience progressive declines. Meanwhile, mildmoderate patients showed high initial cholesterol level and did not decrease during observation. Those with low cholesterol levels showed elevation during observation.

\section{(3}

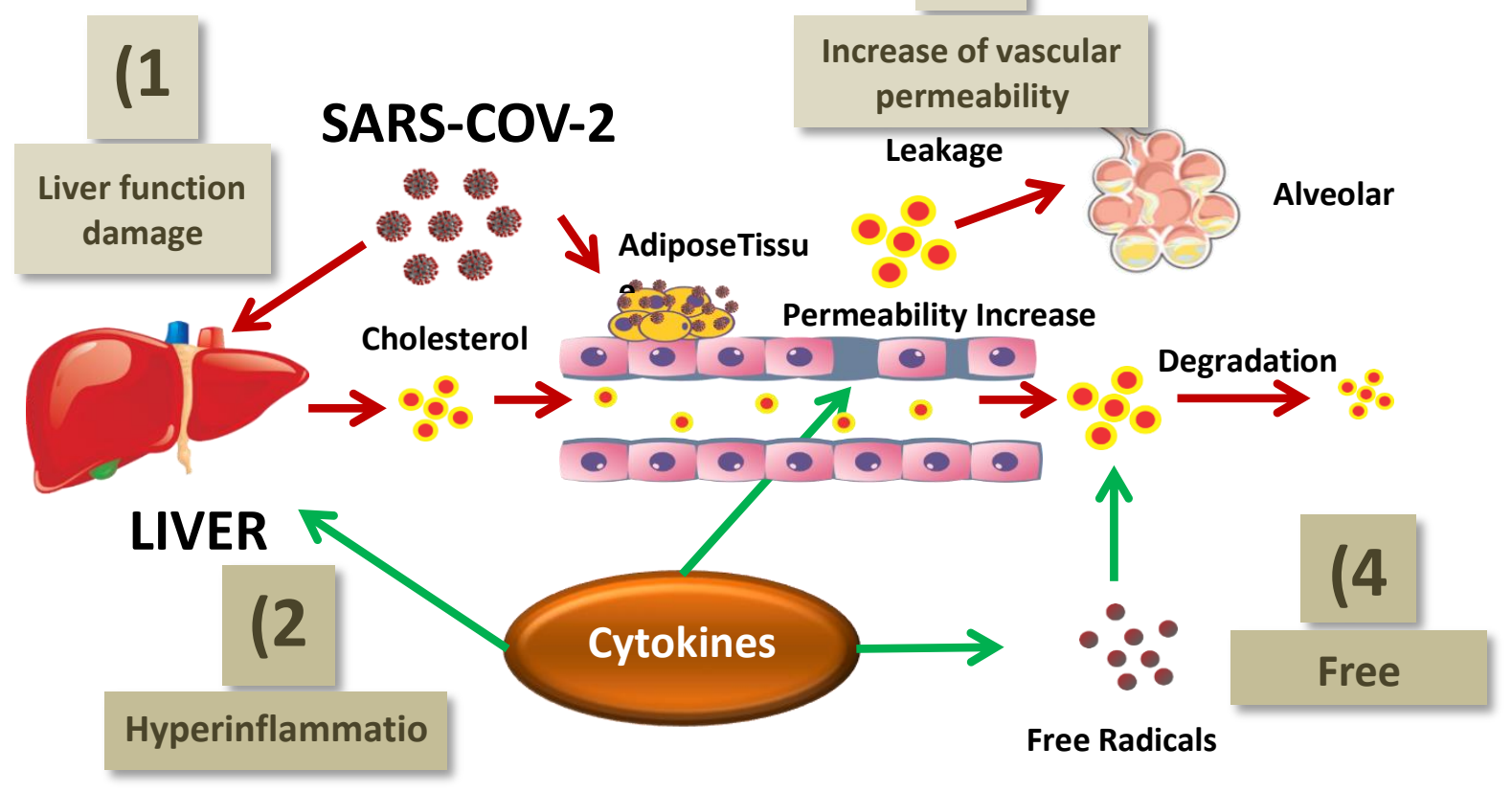

Figure 1. Mechanism of dyslipidemia in COVID-1929 
The dyslipidemia condition in COVID19 is interesting; some mechanisms assumed to play roles in the occurrence of dyslipidemia in COVID-19 showed in Figure 1. ${ }^{29}$ Damage to liver function occurs as a result of SARS-COV-2 infection, which can interfere with LDL uptake and reduce cholesterol biosynthesis. However, AST and ALT only show a slight increase in less than $50 \%$ of the patients. ${ }^{4,5,30}$

This minimal increase of AST and ALT does not accurately describe the liver's LDL uptake and cholesterol biosynthesis ability. As shown in some cases explained previously, the increase of AST and ALT does not always occur in patients with dyslipidemia. Sterol regulatory-element binding protein (SREBPs) is the main transcription factor that manages the expression of various enzymes needed for lipid synthesis. Intracellular lipid homeostasis is regulated by the endoplasm reticulum, where on its membrane there is SREBP cleavage-activating protein (SCAP), squalene monooxygenase (SM), and nuclear factor erythroid two related factor1 (Nrf1). ${ }^{31}$

When the body needs cholesterol, SCAP will bind SREBPs in the endoplasm reticulum, deliver it to Golgi, and facilitate SREBPs proteolysis to produce the factor domain release of SREBP transcription the entry of the nucleus to increase cholesterol synthesis and uptake. It is very reasonable to speculate that cholesterol synthesis and uptake path has changed in COVID-19 patients because recently, there is evidence that SARS-CoV-2 can suppress the amount of protein associated with the cholesterol mechanism. ${ }^{12,30}$

The hyper-inflammatory response generated by SARS-CoV-2 infection alters lipid metabolism. Inflammatory cytokines such as TNF alpha, IL-6, and IL-1 beta have been proven to change lipid composition, function, and transportation in HIV patients. ${ }^{32}$ Cytokines storm in COVID-19 is considered mortality-causing factor in COVID-19 patients. Interleukin-6 increases to $96 \%$ of patients in the research of Fan et al. ${ }^{11}$ It shows that cytokines may contribute to LDL abnormalities in COVID19 patients. ${ }^{5}$ In some cases that have been described above, cholesterol level decrease is correlated with the inflammatory level that occurs, which is marked by the increase of NLR, CRP, LDH, and Ferritin. ${ }^{3}$

The increase of vascular permeability in SARS-CoV-2 infection causes cholesterol leakage to the alveolar and forms exudate that contains proteins and cholesterol. ${ }^{29}$ Exudate has been found in the pulmonary autopsy of SARS patients, such as in pulmonary pathology of COVID-19 patients. ${ }^{33}$

Free radicals are commonly increased in viral infection. ${ }^{5}$ It fastens lipid degradation in COVID-19. Oxidized LDL examination is needed to confirm this possibility. Besides that, cholesterol facilitates SARS protein $S$ bonded with Angiotensin Converting Enzyme (ACE) 2 for entering into the target cells. Adipose tissues may function as a reservoir for SARS-CoV-2. ${ }^{29,34}$

There were some limitations in this case series. First, this case report only 
explains some cases that cannot describe the complete profiles of COVID-19 patients in Ulin Regional Hospital Banjarmasin yet. It needs further research of a bigger scale to prove the correlation between cholesterol level with severity level and mortality of COVID-19 patients and find the roles of cholesterol in SARS-CoV-2 infection. Second, equal treatment among groups should also be noticed regarding the disease onset with the time of cholesterol examination, cholesterol evaluation examination schedule, and the time of cholesterol sample taking. Third, viral load examination may help to determine the virulence level of SARS-CoV2 and whether it is related to the patients' cholesterol level.

\section{CONCLUSION}

This study showed several cases of a higher cholesterol level in asymptomatic and mild-moderate COVID-19 survivors compared to severe-critical and nonsurvivors. Cholesterol is thought to play an important role in the pathological development of COVID-19 and was thought to be associated with severity and mortality, which requires further studies.

\section{REFERENCES}

1. Menteri Kesehatan RI. Kepmenkes HK.01.07/MENKES/413/2020

Pedoman Pencegahan Dan

Pengendalian Coronavirus Disease 2019 (COVID-19) | Direktorat Jenderal Kefarmasian dan Alat Kesehatan.
2020.

2. Lauer SA, Grantz $\mathrm{KH}, \mathrm{Bi} \mathrm{Q}$, et al. The Incubation Period of Coronavirus Disease 2019 (COVID-19) From Publicly Reported Confirmed Cases: Estimation and Application. Ann Intern Med. 2020;172(9):577-582.

3. Guan W, Ni Z, Hu Y, et al. Clinical Characteristics of Coronavirus Disease 2019 in China. N Engl J Med. 2020;382(18):1708-1720.

4. Benvenuto $D$, Giovanetti M, Ciccozzi $A$, Spoto S, Angeletti S, Ciccozzi M. The 2019-new coronavirus epidemic: Evidence for virus evolution. $J$ Med Virol. 2020;92(4):455.

5. Li Q, Guan X, Wu P, et al. Early Transmission Dynamics in Wuhan, China, of Novel Coronavirus-Infected Pneumonia. $N$ Engl $J$ Med. 2020;382(13):1199-1207.

6. Huang $C$, Wang $Y$, Li X et al. Clinical features of patients infected with 2019 novel coronavirus in Wuhan, China. Lancet. 2020;395(10223):497-506.

7. Lu R, Zhao X, Li J, et al. Genomic characterisation and epidemiology of 2019 novel coronavirus: implications for virus origins and receptor binding. Lancet. 2020;395(10224):565-574.

8. Coronaviridae Study Group of the International Committee on Taxonomy of Viruses. The species Severe acute respiratory syndrome-related coronavirus: classifying 2019-nCoV and naming it SARS-CoV-2. Nat Microbiol. 2020;5(4):536-544.

9. Wei $X$, Zeng $W$, Su J, et al. Hypolipidemia is associated with the 
severity of COVID-19. J Clin Lipidol. 2020;14(3):297-304.

10. Wu Q, Zhou L, Sun X, et al. Altered Lipid Metabolism in Recovered SARS Patients Twelve Years after Infection. Sci Reports 2017 71. 2017;7(1):1-12.

11. Fan J, Wang $H$, Ye $G$, et al. Letter to the Editor: Low-density lipoprotein is a potential predictor of poor prognosis in patients with coronavirus disease 2019. Metabolism. 2020;107:154243.

12. Grifoni $A$, Weiskopf $D$, Ramirez $S$, et al. Targets of T Cell Responses to SARSCoV-2 Coronavirus in Humans with COVID-19 Disease and Unexposed Individuals. Cell. 2020;181(7):14891501.e15.

13. Mathur $\mathrm{N}$, Mehta $\mathrm{A}$, Mathur $\mathrm{M}$. Hypolipidemia: a study evaluating magnitude and underlying etiologies of the entity. Int $J$ Adv Med. 2021;8(2):183-185.

14. Bietz $A$, Zhu $H$, Xue $M$, Xu C. Cholesterol Metabolism in $\mathrm{T}$ Cells. Front Immunol. 2017;8(NOV):27.

15. Tachyla SA, Marochkov AV, Lipnitski $A L$, Nikiforova YG. The prognostic value of procalcitonin, C-reactive protein and cholesterol in patients with an infection and multiple organ dysfunction. Korean $J$ Anesthesiol. 2017;70(3):305.

16. Metwally M, Raheem HA. Lipid Profile in Tuberculous Patients: A Preliminary Report. Life Sci J. 2012;9(1):719-722.

17. Surya Wahyudi S, Soebadi DM, Hardjowijoto S. Total Cholesterol and C-reactive Protein (CRP) Levels as Prognostic Markers for Urosepsis.
Indian J Public Heal Res Dev. 2019;10(4):1217-1222.

18. Rogers AJ, Leligdowicz A, Contrepois $\mathrm{K}$, et al. Plasma Metabolites in Early Sepsis Identify Distinct Clusters Defined by Plasma Lipids. Crit Care Explor. 2021;3(8):e0478.

19. Nassaji M, Ghorbani R. Plasma lipid levels in patients with acute bacterial infections. J Med Sci. 2012;42(3):465469. doi:1011-1278

20. Aldabbagh L, Rajooj Hmood A, Khalid Faleeh Aldahalemi D, Almuhana S, Sadiq Almussawi A. Dyslipidemia in patients with hepatitis $\mathrm{C}$ virus infection. Ann Trop Med Public Heal http Aladabbagh al. 2020;23(9).

21. Arisar FAQ, Khan SB, Umar A, et al. Changes in Serum Lipid Profile among Patients Suffering from Chronic Liver Disease Secondary to Hepatitis C. Open J Gastroenterol. 2016;6(11):333-342.

22. Cao W, Wang T, Gao Y, Wang Y, Bao T, Zou G. Serum Lipid Metabolic Derangement is Associated with Disease Progression During Chronic HBV Infection. Clin $L a b$. 2019;65(12):2377-2386.

23. Lima W, Souza N, Fernandes S, Cardoso V, Godói I. Serum lipid profile as a predictor of dengue severity: $A$ systematic review and meta-analysis. Rev Med Virol. 2019;29(5).

24. Parrettini S, Caroli A, Torlone E. Nutrition and Metabolic Adaptations in Physiological and Complicated Pregnancy: Focus on Obesity and Gestational Diabetes. Front Endocrinol 
(Lausanne). 2020;11.

25. Grundy SM, Stone NJ, Chair V, et al. 2018

AHA/ACC/AACVPR/AAPA/ABC/ACPM/A

DA/ AGS/APhA/ASPC/NLA/PCNA

Guideline on the Management of Blood

Cholesterol Circulation. Circulation. 2019;139:1082-1143.

26. Jiang $\mathrm{S}$, Jiang J, $\mathrm{Xu} \mathrm{H}$, et al. Maternal dyslipidemia during pregnancy may increase the risk of preterm birth: $A$ meta-analysis. Taiwan $J$ Obstet Gynecol. 2017;56(1):9-15.

27. Chen $L$, Li Q, Zheng $D$, et al. Clinical Characteristics of Pregnant Women with Covid-19 in Wuhan, China. N Engl J Med. 2020;382(25):e100.

28. Zhu $H$, Wang $L$, Fang $C$, et al. Clinical analysis of 10 neonates born to mothers with 2019-nCoV pneumonia. Transl Pediatr. 2020;9(1):51.

29. Panahi L, Amiri M, Pouy S. Risks of Novel Coronavirus Disease (COVID19) in Pregnancy; a Narrative Review. Arch Acad Emerg Med. 2020;8(1):1-5.

30. Cao X, Yin R, Albrecht $H$, Fan D, Tan $W$. Cholesterol: A new game player accelerating vasculopathy caused by SARS-CoV-2? Am J Physiol Endocrinol Metab. 2020;319(1):E197-E202.

31. Wei $X$, Su J, Yang $K$, et al. Elevations of serum cancer biomarkers correlate with severity of COVID-19. J Med Virol. 2020;92(10):2036-2041.

32. Chua N, Howe V, Jatana N, Thukral L, Brown A. A conserved degron containing an amphipathic helix regulates the cholesterol-mediated turnover of human squalene monooxygenase, a rate-limiting enzyme in cholesterol synthesis. $J$ Biol Chem. 2017;292(49):19959-19973.

33. Funderburg NT, Mehta NN. Lipid Abnormalities and Inflammation in HIV inflection. Curr HIV/AIDS Rep. 2016;13(4):218.

34. Tian $S$, Hu W, Niu L, Liu $H, X u H$, Xiao S. Pulmonary Pathology of Early-Phase 2019 Novel Coronavirus (COVID-19) Pneumonia in Two Patients With Lung Cancer. J Thorac Oncol. 2020;15(5):700-704. 